Bul. Agrohorti 1 (4) : 51 - 57 (2013)

\title{
Controlled Deterioration Test untuk Menguji Ketahanan Benih Kacang Hijau (Phaseolus radiatus L.) terhadap Kondisi Cekaman Kekeringan
}

\section{Controlled Deterioration Test to Determine the Resistance of Mungbean Seed (Phaseolus radiatus L.) Against Drought Stress}

\author{
Indra Kurniawati *, Endang Murniati
}

Departemen Agronomi dan Hortikultura, Fakultas Pertanian, Institut Pertanian Bogor (Bogor Agricultural University), Jl. Meranti, Kampus IPB Darmaga, Bogor 16680, Indonesia Telp. \& Faks.62-251-8629353, e-mail agronipb@indo.net.id *Penulis untuk korespondensi: indrakurnia_10@yahoo.co.id

Disetujui 24 Desember 2013/ Published Online 10 Januari 2014

\begin{abstract}
The research was conducted from February to April 2012 at the Seed Science and Technology Laboratory, Agronomy and Horticulture Department, Bogor Agricultural University. This research consist of three experiment. The first experiment was to determine the tolerance of five varieties of mungbean seeds to drought using PEG 6000 with different levels of osmotic pressure (0, -0.5, -1, -2, and -3 bar). The second experiment, determining the seed vigor of five mungbean seed lots using controlled deterioration test (CDT) with condition of temperature was $45^{\circ} \mathrm{C}$, the seed moisture content were $20 \%, 22 \%, 24 \%$, $26 \%$ and the deterioration time were $0 \mathrm{~h}, 24 \mathrm{~h}, 48 \mathrm{~h}, 72 \mathrm{~h}$. The experimental design that used was randomized complete block design with two factor. The third experiment was to determine the relationship between the results of first experiment with the second experiment results. The third experiment also could show the effectiveness of the CDT method in testing the resistance of mungbean seeds against drought stress. Based on the observations of the variable results, it was obtained that the -1 bar PEG 6000 had capability of selecting seeds that were resistant and not resistant to drought. The result of the second experiment was CDT conditions that can be used to test for seed vigor were 20\%/48 hours and 22\%/24 hours. Correlation analysis between the variables in the 1 bar PEG 6000 with CDT on two conditions CDT (20\%/48 hours and 22\%/24 hours) showed significant correlation to the normal germination percent $(r=0.61$ and 0.58$)$ and speed germination $(r=0.62$ and 0.59$)$.
\end{abstract}

Kata kunci : PEG 6000, uji vigor

\section{ABSTRAK}

Penelitian ini dilakukan di Laboratorium Ilmu dan Teknologi Benih, Departemen Agronomi dan Hortikultura, Institut Pertanian Bogor pada bulan Februari-April 2012. Percobaan pertama bertujuan untuk menentukan toleransi benih beberapa varietas kacang hijau terhadap cekaman kekeringan menggunakan PEG 6000 dengan berbagai tingkat tekanan osmotik (0, -0.5, -1, -2 dan -3) bar. Percobaan kedua, Controlled Deterioration Test (CDT) dengan suhu $45^{\circ} \mathrm{C}$, kadar air 20\%, 22\%, 24\% dan $26 \%$ serta lama penderaan 0 jam, 24 jam, 48 jam dan 72 jam bertujuan untuk mendapatkan kondisi air benih dan lama penderaan yang efektif untuk menguji vigor lima varietas benih kacang hijau. Rancangan percobaan yang digunakan adalah Rancangan Kelompok Lengkap Teracak dua faktor. Percobaan ketiga bertujuan untuk mengetahui tingkat keeratan hubungan antara hasil percobaan pertama dan percobaan kedua, sehingga dapat diketahui keefektifan metode CDT sebagai indikator dalam menguji ketahanan benih kacang hijau terhadap cekaman kekeringan. Berdasarkan hasil pengamatan terhadap variabel $K_{C T}$ dan IV diperoleh hasil bahwa PEG 6000 yang mampu menyeleksi benih yang tahan dan tidak tahan terhadap kekeringan adalah tekanan osmotik -1 bar. Hasil dari percobaan dua yaitu kondisi CDT yang dapat digunakan untuk menguji vigor benih adalah kondisi CDT (kadar air/lama penderaan) 20\%/48 jam dan 22\%/24 jam. Hasil analisis korelasi antara variabel-variabel pada tekanan osmotik PEG 6000 - 1 bar dengan $V_{C D T}$ pada dua kondisi CDT (20\%/48 jam dan 22\%/24 jam) menunjukkan korelasi nyata pada variabel $\% K N\left(r=0.61\right.$ dan 0.58) dan $K_{C T}(r=0.62$ dan 0.59). 


\section{PENDAHULUAN}

Kacang hijau merupakan tanaman palawija yang banyak ditanam oleh petani di Indonesia setelah padi, jagung, kedelai dan kacang tanah. Untuk meningkatkan produksi kacang hijau, perlu pengembangan kacang hijau yang ditanam di lahan kering. Lahan kering di Indonesia yang sesuai untuk lahan pertanian mencapai sekitar 76.22 juta ha $(52 \%)$ dari total luas 148 juta ha (Abdurachman et al., 2008). Hal ini menunjukkan bahwa kacang hijau berpotensi untuk dikembangkan lebih lanjut khususnya di daerah kering agar produksinya dapat dipenuhi.

Pengujian benih dilakukan dengan cara simulasi kondisi kekeringan menggunakan Polyethylen Glycol (PEG). Penggunaan PEG menyebabkan penurunan potensial air secara homogen sehingga dapat digunakan untuk meniru besarnya potensial air tanah (Michel dan Kaufman, 1973). PEG telah digunakan pada perkecambahan kacang hijau dengan konsentrasi PEG -0.05 Mpa, $0.2 \mathrm{Mpa},-0.5$ dan -1 Mpa yang ditanam dalam media pasir (Zayed dan Zeid, 1997), untuk identifikasi somaklonal beberapa varietas padi tahan kekeringan menggunakan PEG (Lestari dan Mariska, 2006) serta untuk menyeleksi genotipe kacang hijau terhadap cekaman kekeringan pada tekanan osmotik -3 bar (Dutta dan Bera, 2008).

Metode menggunakan PEG tergolong sederhana dan singkat, namun memiliki kelemahan antara lain harga PEG yang relatif mahal dan sering terjadinya kontaminasi cendawan pada saat benih dikecambahkan, sehingga diperlukan alternatif pengujian vigor benih yang berkolerasi dengan ketahanan benih terhadap cekaman kekeringan. Controlled deterioration test (CDT) merupakan metode pengujian vigor benih untuk mengetahui kualitas benih yang akan digunakan. Menurut Powell dan Mattews dalam Wafiroh (2010) menyatakan bahwa metode CDT menggambarkan proses kemunduran suatu lot benih. Kadar air, suhu, dan lama penderaan yang sering digunakan dalam metode $C D T$ adalah $20 \%$ dengan suhu $45^{\circ} \mathrm{C}$ dan periode penderaan 24 jam. Metode $C D T$ juga telah dilakukan pada legum lainnya seperti pada kedelai dengan kondisi $C D T$ suhu $41^{\circ} \mathrm{C}$ dan lama penderaan 72 jam untuk menguji ketahanan benih kedelai terhadap deraan cuaca di lapang (Changrong et al., 2007).

Pengujian benih kacang hijau terhadap cekaman kekeringan dengan metode $C D T$ diharapkan mendapatkan hasil yang sama seperti penelitian sebelumnya serta dapat digunakan untuk mengembangkan metode pengujian untuk identifikasi vigor benih terhadap cekaman kekeringan yang lebih mudah dan sederhana.

Penelitian ini bertujuan untuk mencari varietas kacang hijau yang toleran terhadap kondisi kekeringan secara simulatif di laboratorium, mencari kondisi (kadar air, suhu dan waktu penderaan) $C D T$ yang tepat untuk menguji vigor benih kacang hijau serta menentukan tingkat korelasi viabilitas pada $C D T\left(\mathrm{~V}_{C D T}\right)$ dengan beberapa variabel vigor kekuatan tumbuh terhadap kekeringan $\left(\mathrm{V}_{\mathrm{KT}^{\mathrm{T}}}{ }^{\text {kekeringan }}\right)$.

\section{BAHAN DAN METODE}

Penelitian ini dilaksanakan di Laboratorium Ilmu dan Teknologi Benih Departemen Agronomi dan Hortikultura, IPB Darmaga pada bulan Februari - April 2012.

Bahan yang digunakan meliputi lima lot benih kacang hijau yaitu varietas Walet, Sriti, Murai, Kutilang dan Vima-1 yang diperoleh dari Balai Penelitian Kacang-kacangan dan Umbiumbian, Malang. Bahan lainnya yaitu PEG 6000, aquades, aluminium foil, kertas stensil, plastik PE, dan kertas label. Alat yang digunakan pada percobaan pertama adalah alat pengecambah benih tipe IPB 72-1, kuas, gelas piala, magnetic stirrer. Alat yang digunakan pada percobaan kedua yaitu oven, neraca digital, desikator, sealer, refrigerator, water bath, alat pengecambah benih tipe IPB 72-1, alat pengepres kertas, pinset, handsprayer.

Kegiatan penelitian terdiri atas tiga percobaan. Percobaan pertama menggunakan PEG 6000 dengan berbagai tingkat tekanan osmotik. Rancangan yang digunakan adalah Rancangan Kelompok Lengkap Teracak (RKLT) faktorial dua faktor dengan tiga ulangan. Faktor pertama yaitu lima lot benih varietas Walet, Sriti, Murai, Kutilang dan Vima-1. Faktor kedua adalah pemberian PEG 6000 dengan lima taraf yaitu $0,-0.5,-1,-2$ dan -3 bar.

Percobaan kedua menggunakan rancangan percobaan RKLT dua faktor tiga ulangan. Faktor pertama adalah lot benih dengan lima taraf yaitu Walet, Sriti, Murai, Kutilang dan Vima-1. Faktor kedua adalah perlakuan kondisi tingkat kadar air benih (KA) dan lama penderaan (P) dengan 16 taraf yaitu: P0 (20\%/0 jam), P1 (20\%/24 jam), P2 (20\%/48 jam), P3 (20\%/72 jam), P4 (22\%/0 jam), P5 (22\%/24 jam), P5 (22\%/48 jam), P7 (22\%/72 jam), P8 (24\%/0 jam), P9 (24\%/24 jam), P10 
(24\%/48 jam), P11 (24\%/72 jam), P12 (26\%/0 jam), P13 (26\%/24 jam), P14 (26\%/48 jam), P15 (24\%/48 jam), dan P16 (24\%/72 jam). Percobaan pertama dan kedua kemudian diuji lanjut dengan uji DMRT pada taraf nyata $5 \%$.

Percobaan ketiga, berbagai variabel pengamatan hasil percobaan pertama terpilih selanjutnya dikorelasikan dengan $\mathrm{V}_{C D T}$ hasil percobaan kedua. Analisis data dilakukan dengan menggunakan analisis korelasi sederhana antara $\mathrm{V}_{\mathrm{KT}}{ }^{\text {kekeringan }}$ dengan $\mathrm{V}_{C D T}$. Tingkat hubungan $\mathrm{V}_{\mathrm{KT}}{ }^{\text {kekeringan }}$ dengan $\mathrm{V}_{C D T}$ ditentukan oleh nilai koefisien korelasi. Selain itu dilakukan juga analisis regresi linier sederhana dimana variabel $\mathrm{V}_{C D T}$ difungsikan sebagai faktor $X$ dan variabel $\mathrm{V}_{\mathrm{KT}}{ }^{\text {kekeringan }}$ sebagai faktor $\mathrm{Y}$ dalam persamaan regresi tersebut. Persamaan regresi yang digunakan adalah $\mathrm{Yi}=\alpha+\beta \mathrm{Xi} ;\left(\mathrm{Yi}=\right.$ Tolok ukur $\mathrm{V}_{\mathrm{KT}} ; \alpha=$ Intersep; $\beta=$ Kemiringan atau gradient ; $\mathrm{Xi}=\mathrm{V}_{C D T}$ ).

Pelaksanaan percobaan pertama dilakukan dengan menanam benih pada kertas stensil yang dilembabkan dengan larutan PEG 6000. Tingkat tekanan osmotik PEG 6000 terdiri dari lima tingkat yaitu $-0.5,-1,-2$ dan -3 bar. Benih dikecambahkan dengan metode UKDdp dan dimasukkan ke dalam APB IPB 72-1. Percobaan kedua, masing-masing lot benih ditingkatkan kadar airnya menjadi $20 \%$, $22 \%$, 24\%, dan 26\%. Benih dimasukkan dalam alumunium foil dan ditambahkan aquades sesuai perlakuan kadar air benih. Benih dalam alumuniun foil yang telah memiliki kadar air yang sesuai dimasukkan ke dalam refrigerator bersuhu $4^{\circ} \mathrm{C}$ dan didiamkan semalaman, agar benih berimbibisi dan diperoleh benih dengan tingkat kadar air yang diinginkan sesuai perlakuan. Benih kemudian dimasukkan dalam water bath bersuhu $45^{\circ} \mathrm{C}$ selama 0, 24, 48, dan $72 \mathrm{jam}$. Benih kemudian diuji dengan metode UKDdp dan dimasukkan dalam APB IPB 72-1. Hasil dari percobaan pertama dan kedua terpilih diuji korelasinya menggunakan analisis korelasi sederhana serta analisis regresi linier sederhana antara $\mathrm{V}_{\mathrm{KT}}$ kekeringan dengan $\mathrm{V}_{\text {CDT }}$. Tingkat hubungan antara $\mathrm{V}_{\mathrm{KT}}{ }^{\text {kekeringan }}$ dengan $\mathrm{V}_{C D T}$ ditentukan oleh nilai koefisien korelasi (r) dan didukung oleh nilai koefisien determinasi $\left(\mathrm{R}^{2}\right)$.

\section{Pengamatan}

Pengamatan pada percobaan pertama dan kedua di laboratorium dilakukan terhadap variabel kadar air (KA), persentase kecambah normal $(\% \mathrm{KN})$, kecepatan tumbuh $\left(\mathrm{K}_{\mathrm{CT}}\right)$, indeks vigor (IV), panjang akar (PA) kecambah normal, panjang hipokotil $(\mathrm{PH})$ kecambah normal, dan bobot kering kecambah normal (BKKN).

\section{HASIL DAN PEMBAHASAN}

\section{Pengaruh Varietas dan Tekanan Osmotik PEG 6000 terhadap Vigor Kekeringan}

Hasil analisis ragam dari perlakuan pengaruh varietas dan tekanan osmotik PEG 6000 terhadap variabel $\% \mathrm{KN}, \mathrm{K}_{\mathrm{CT}}$, IV, $\mathrm{PA}, \mathrm{PH}$ serta $\mathrm{BKKN}$ yaitu faktor varietas menunjukkan pengaruh yang sangat nyata terhadap semua variabel kecuali pada $\mathrm{PH}$. Faktor tekanan osmotik PEG 6000 menunjukkan pengaruh sangat nyata terhadap semua variabel yang diamati. Hasil analisis statistik menunjukkan adanya interaksi sangat nyata terhadap variabel $\% \mathrm{KN}, \mathrm{K}_{\mathrm{CT}}$, IV dan BKKN, sedangkan pada PA dan PH menunjukkan interaksi nyata. Pengaruh interaksi kedua faktor pada semua variabel ditunjukkan pada Tabel 1.

Berdasarkan Tabel 1, tekanan osmotik -0.5 bar pada variabel pengamatan $\% \mathrm{KN}$ dan IV menunjukkan bahwa viabilitas dan vigor benih masih belum bisa dibedakan kecuali pada Vima-1 yang sudah rendah dan untuk keempat varietas lainnya masih belum terlihat perbedaan. Pada variabel $\mathrm{K}_{\mathrm{CT}}$ dan $\mathrm{BKKN}$ sudah terlihat perbedaan secara statistik dengan 0 bar namun dari kelima varietas tidak berbeda nyata kecuali varietas Vima1.

Tabel 1 menunjukkan bahwa tekanan -2 bar dan -3 bar hampir semua varietas sudah tidak dapat dibedakan karena nilai-nilainya sudah sangat rendah. Benih kacang hijau sudah tidak mampu berkecambah secara normal dan banyak terserang cendawan. Hal ini sejalan dengan penelitian Widoretno (2002) yang menyatakan bahwa perkecambahan benih kedelai menurun akibat meningkatnya konsentrasi PEG pada media perkecambahan. Hal ini diduga terjadi karena semakin terhambatnya proses metabolisme sel akibat cekaman kekeringan yang disimulasikan dengan PEG 6000.

Respon tanaman terhadap kekeringan tergantung sifat tanaman. Pada variabel $\mathrm{PH}$ menunjukkan respon $\mathrm{PH}$ yang semakin pendek bahkan pada tekanan osmotik -3 bar pada $\mathrm{PH}$, benih banyak terserang cendawan dan tidak mampu berkecambah. Hal ini sejalan dengan penelitian Widoretno (2002) pada kedelai, panjang hipokotil kecambah lebih sensitif terhadap cekaman kekeringan dibandingkan dengan panjang akar kecambah. Panjang hipokotil pada penelitian tersebut menurun akibat pemberian PEG 6000. Hal ini diduga terjadi akibat terhambatnya proses pembelahan sel, pemanjangan sel, atau keduanya 
akibat cekaman kekeringan yang disimulasikan dengan PEG.

Tabel 1. Interaksi varietas dan tekanan osmotik PEG 6000 terhadap beberapa variabel yang diamati

\begin{tabular}{|c|c|c|c|c|c|}
\hline \multirow{2}{*}{ Varietas } & \multicolumn{5}{|c|}{ Tekanan osmotik PEG 6000} \\
\hline & $\mathbf{0}$ & -0.5 & -1 & -2 & -3 \\
\hline \multicolumn{6}{|c|}{--------Persentase Kecambah Normal-------- } \\
\hline Walet & $95.33^{\mathrm{a}}$ & $96.00^{\mathrm{a}}$ & $84.00^{\mathrm{a}}$ & $36.67^{\mathrm{dc}}$ & $1.33^{\mathrm{e}}$ \\
\hline Sriti & $99.33^{\mathrm{a}}$ & $96.00^{\mathrm{a}}$ & $92.67^{\mathrm{a}}$ & $46.00^{\mathrm{bcd}}$ & $2.00^{\mathrm{e}}$ \\
\hline Murai & $98.67^{\mathrm{a}}$ & $92.00^{\mathrm{a}}$ & $70.00^{\mathrm{ab}}$ & $26.00^{\mathrm{d}}$ & $1.33^{\mathrm{e}}$ \\
\hline Kutilang & $98.67^{\mathrm{a}}$ & $91.33^{\mathrm{a}}$ & $57.33^{a b c}$ & $20.00^{\mathrm{d}}$ & $0.00^{\mathrm{e}}$ \\
\hline Vima-1 & $87.33^{\mathrm{a}}$ & $40.00^{\mathrm{dc}}$ & $19.33^{\mathrm{d}}$ & $0.00^{\mathrm{e}}$ & $0.00^{\mathrm{e}}$ \\
\hline \multicolumn{6}{|c|}{--------Kecepatan Tumbuh (\%/etmal)------- } \\
\hline Walet & $31.50^{\mathrm{ab}}$ & $22.94^{\mathrm{cd}}$ & $15.69^{\text {ef }}$ & $5.81^{\text {hi }}$ & $0.19^{\mathrm{j}}$ \\
\hline Sriti & $32.32^{\mathrm{a}}$ & $24.21^{\mathrm{cd}}$ & $17.22^{\mathrm{def}}$ & 7.13 hi & $0.29^{\mathrm{j}}$ \\
\hline Murai & $31.99^{\mathrm{ab}}$ & 20.77 de & $11.78^{\text {gf }}$ & $3.83^{\mathrm{i}}$ & $0.19^{\mathrm{j}}$ \\
\hline Kutilang & $31.61^{\mathrm{ab}}$ & $19.26^{\mathrm{de}}$ & $9.69^{\mathrm{gh}}$ & $3.17^{\mathrm{i}}$ & $0.00^{\mathrm{j}}$ \\
\hline Vima-1 & $29.00^{\mathrm{abc}}$ & $8.10^{\mathrm{h}}$ & $3.24^{\mathrm{i}}$ & $0.00^{\mathrm{j}}$ & $0.00^{\mathrm{j}}$ \\
\hline \multicolumn{6}{|c|}{-------------Indeks Vigor (\%)-------------- } \\
\hline Walet & $94.67^{\mathrm{a}}$ & $77.33^{\mathrm{ab}}$ & $43.33^{\mathrm{c}}$ & $5.33^{\mathrm{e}}$ & $0.00^{\mathrm{f}}$ \\
\hline Sriti & $99.33^{\mathrm{a}}$ & $84.67^{\mathrm{a}}$ & $48.67^{b c}$ & $3.33^{\text {ef }}$ & $0.00^{f}$ \\
\hline Murai & $98.67^{\mathrm{a}}$ & $79.33^{\mathrm{a}}$ & $20.00^{\mathrm{d}}$ & $0.00^{\mathrm{f}}$ & $0.00^{f}$ \\
\hline Kutilang & $98.00^{\mathrm{a}}$ & $67.33^{a b c}$ & $16.67^{\mathrm{d}}$ & $4.00^{\mathrm{e}}$ & $0.00^{\mathrm{f}}$ \\
\hline Vima-1 & $87.33^{\mathrm{a}}$ & $27.33^{\mathrm{d}}$ & $4.67^{\mathrm{e}}$ & $0.00^{\mathrm{f}}$ & $0.00^{f}$ \\
\hline \multicolumn{6}{|c|}{ 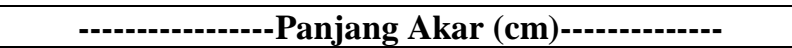 } \\
\hline Walet & $12.4^{\mathrm{a}}$ & $11.9^{a b}$ & $11.9^{a b}$ & $8.4^{\mathrm{abc}}$ & $3.2^{\mathrm{dc}}$ \\
\hline Sriti & $12.2^{\mathrm{ab}}$ & $10.8^{\mathrm{ab}}$ & $11.1^{\mathrm{ab}}$ & $10.8^{\mathrm{ab}}$ & $0.0^{\mathrm{d}}$ \\
\hline Murai & $12.8^{\mathrm{a}}$ & $11.2^{\mathrm{ab}}$ & $12.0^{\mathrm{ab}}$ & $10.3^{\mathrm{ab}}$ & $0.0^{\mathrm{d}}$ \\
\hline Kutilang & $12.7^{\mathrm{a}}$ & $11.2^{\mathrm{ab}}$ & $10.8^{a b}$ & $6.9^{\mathrm{abc}}$ & $0.0^{\mathrm{d}}$ \\
\hline Vima-1 & $12.3^{\mathrm{ab}}$ & $9.4^{\mathrm{ab}}$ & $6.1^{\mathrm{bc}}$ & $0.0^{\mathrm{d}}$ & $0.0^{\mathrm{d}}$ \\
\hline \multicolumn{6}{|c|}{-----------Panjang Hipokotil (cm)------------- } \\
\hline Walet & $12.0^{\mathrm{a}}$ & $5.0^{\mathrm{c}-\mathrm{f}}$ & $4.2^{\mathrm{c}-\mathrm{f}}$ & $2.6^{\mathrm{f}-\mathrm{h}}$ & $0.7^{\mathrm{hi}}$ \\
\hline Sriti & $11.1^{\mathrm{a}}$ & $7.9^{\mathrm{a}-\mathrm{c}}$ & $4.2^{c-f}$ & $4.2^{\mathrm{c}-\mathrm{f}}$ & $0.0^{\mathrm{i}}$ \\
\hline Murai & $11.0^{\mathrm{a}}$ & $7.6^{\mathrm{a}-\mathrm{c}}$ & $5.7^{\mathrm{b}-\mathrm{e}}$ & $2.9^{\mathrm{a}-\mathrm{g}}$ & $0.0^{\mathrm{i}}$ \\
\hline Kutilang & $10.4^{\mathrm{ab}}$ & $6.7^{\mathrm{a}-\mathrm{d}}$ & $4.6^{\mathrm{c}-\mathrm{f}}$ & $1.5^{\mathrm{gh}}$ & $0.0^{\mathrm{i}}$ \\
\hline Vima-1 & $11.8^{\mathrm{a}}$ & $8.2^{\mathrm{a}-\mathrm{c}}$ & $4.9^{\mathrm{d}-\mathrm{f}}$ & $0.0^{\mathrm{i}}$ & $0.0^{\mathrm{i}}$ \\
\hline \multicolumn{6}{|c|}{ 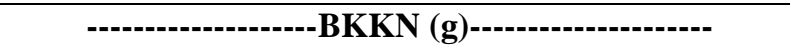 } \\
\hline Walet & $1.27^{\mathrm{b}}$ & $0.68^{\text {def }}$ & 0.57 efg & $0.11^{\mathrm{j}}$ & $0.01^{\mathrm{j}}$ \\
\hline Sriti & $1.34^{\mathrm{ab}}$ & $1.06^{\mathrm{bc}}$ & $0.44^{\text {efg }}$ & $0.18^{\mathrm{ij}}$ & $0.00^{\mathrm{j}}$ \\
\hline Murai & $1.64^{\mathrm{a}}$ & $0.92 \mathrm{dc}$ & $0.35^{\text {ghi }}$ & $0.06^{\mathrm{j}}$ & $0.00^{\mathrm{j}}$ \\
\hline Kutilang & $1.65^{\mathrm{a}}$ & $0.76^{\mathrm{de}}$ & 0.34 ghi & $0.03^{\mathrm{j}}$ & $0.00^{\mathrm{j}}$ \\
\hline Vima-1 & $1.19 \mathrm{bc}$ & 0.32 hi & $0.07^{\mathrm{j}}$ & $0.00^{\mathrm{j}}$ & $0.00^{\mathrm{j}}$ \\
\hline Ket: Nila & ang diik & $\begin{array}{l}\text { ti huruf y } \\
\text { beda untu } \\
\text { ada uji D }\end{array}$ & $\begin{array}{l}\text { sama } \\
\text { etiap va } \\
\text { T taraf }\end{array}$ & $\begin{array}{l}\text { a baris da } \\
\text { gel tidak } \\
\text {; data }\end{array}$ & \\
\hline
\end{tabular}

Pada kondisi -1 bar variabel $\mathrm{K}_{\mathrm{CT}}$, varietas Sriti tidak berbeda nyata dengan varietas Walet dan Murai, Murai tidak berbeda nyata dengan Kutilang. Varietas Vima-1 berbeda nyata dengan keempat varietas lainnya. Pada variabel IV varietas Walet dan Sriti tidak berbeda nyata, keduanya berbeda nyata dengan Murai, Kutilang dan Vima-1. Berdasarkan hal tersebut maka varietas Walet dan Sriti merupakan varietas tahan terhadap cekaman kekeringan. Hal ini sesuai dengan deskripsi varietas Sriti yang menyatakan bahwa varietas Sriti beradaptasi baik pada keadaan kering (Balitkabi, 2005).

$\mathrm{K}_{\mathrm{CT}}$ dan IV benih yang tinggi menunjukkan benih berkecambah lebih cepat sehingga digolongkan dalam benih yang vigor. Menurut Sadjad (1999), kecepatan tumbuh benih mengindikasikan viabilitas benih karena benih yang cepat tumbuh lebih mampu menghadapi kondisi lapangan yang suboptimum. Semakin tinggi nilai $\mathrm{K}_{\mathrm{CT}}$ maka semakin bagus pula vigor benih tersebut karena benih mampu berkecambah dalam waktu yang relatif lebih singkat.

Berdasarkan hasil pengamatan yang telah dilakukan, variabel $\mathrm{K}_{\mathrm{CT}}$ dan IV merupakan variabel yang dapat menyeleksi lima varietas benih yang digunakan dan PEG 6000 yang mampu menyeleksi benih adalah tekanan osmotik -1 bar. Dari kelima varietas kacang hijau yang digunakan dapat dikelompokkan varietas yang tahan kekeringan adalah varietas Sriti dan Walet dan yang tidak tahan cekaman kekeringan adalah varietas Murai, Kutilang dan Vima-1. Berdasarkan hal tersebut, penggunaan PEG 6000 sebagai bahan untuk pengujian cekaman kekeringan telah sesuai untuk menguji lot benih yang tahan dan tidak tahan terhadap cekaman kekeringan pada tekanan osmotik -1 bar dengan variabel pengamatan $\mathrm{K}_{\mathrm{CT}}$ dan IV.

Pengaruh Varietas dan Kondisi CDT (Kadar Air, Suhu, serta Lama Penderaan) terhadap Viabilitas

Hasil analisis statistik menunjukkan faktor varietas berpengaruh sangat nyata pada semua variabel kecuali $\mathrm{PH}$, sedangkan kondisi $C D T$ berpengaruh sangat nyata pada semua variabel. Interaksi kedua faktor tidak berpengaruh nyata pada variabel $\% \mathrm{KN}, \mathrm{K}_{\mathrm{CT}}$, dan IV. Pengaruh faktor tunggal varietas dan $C D T$ pada variabel $\% \mathrm{KN}$ ditunjukkan pada Tabel 2. Tabel 2 menunjukkan bahwa pengaruh varietas terhadap \%KN memberikan respon yang tidak berbeda nyata kecuali pada varietas Vima-1. Pengaruh kondisi $C D T$ terhadap \% KN menunjukkan bahwa kondisi 0 jam dengan semua tingkat kadar air tidak berbeda nyata. Pengaruh kondisi $C D T$ mulai terlihat pada kondisi 20\%/48 jam yang berbeda dengan 0 jam. 
Bul. Agrohorti 1 (4) : 51 - 57 (2013)

Tabel 2. Pengaruh faktor tunggal varietas dan kondisi $C D T$ terhadap $\% \mathrm{KN}$

\begin{tabular}{crrrrrr}
\hline Kondisi $C D T(\mathrm{KA} /$ Lama & \multicolumn{3}{c}{ Varietas } & \multicolumn{2}{c}{ Rataan } \\
\cline { 2 - 5 } penderaan) & Walet & \multicolumn{1}{c}{ Sriti } & Murai & Kutilang & Vima-1 & \\
\hline $20 / 0$ jam & 92.00 & 98.67 & 99.33 & 98.67 & 92.67 & $96.00 \mathrm{a}$ \\
$20 \% / 24$ jam & 75.33 & 72.67 & 90.00 & 83.33 & 56.67 & $74.85 \mathrm{ab}$ \\
$20 \% / 48$ jam & 51.33 & 70.67 & 69.00 & 70.00 & 30.00 & $56.15 \mathrm{bc}$ \\
$20 \% / 72$ jam & 48.00 & 52.00 & 71.33 & 71.33 & 30.67 & $52.85 \mathrm{c}$ \\
\hline $22 \% / 0$ jam & 92.67 & 98.67 & 98.00 & 98.00 & 84.67 & $94.28 \mathrm{a}$ \\
$22 \% / 24$ jam & 52.00 & 85.33 & 88.67 & 66.00 & 35.33 & $65.46 \mathrm{bc}$ \\
$22 \% / 48$ jam & 55.33 & 66.67 & 34.67 & 24.67 & 12.67 & $38.66 \mathrm{de}$ \\
$22 \% / 72$ jam & 26.67 & 16.67 & 37.33 & 32.67 & 26.00 & $30.26 \mathrm{e}$ \\
\hline $24 \% / 0$ jam & 92.00 & 98.00 & 98.00 & 96.67 & 84.67 & $93.86 \mathrm{a}$ \\
$24 \% / 24$ jam & 45.33 & 58.67 & 64.67 & 42.00 & 18.67 & $45.86 \mathrm{dc}$ \\
$24 \% / 48$ jam & 10.67 & 26.00 & 16.67 & 12.67 & 6.00 & $14.40 \mathrm{f}$ \\
$24 \% / 72$ jam & 14.67 & 5.33 & 14.67 & 28.67 & 16.67 & $16.00 \mathrm{f}$ \\
\hline $26 / 0$ jam & 87.33 & 95.33 & 97.33 & 98.67 & 78.67 & $91.46 \mathrm{a}$ \\
$26 \% / 24$ jam & 28.00 & 38.67 & 43.33 & 32.67 & 8.67 & $30.26 \mathrm{e}$ \\
$26 \% / 48$ jam & 2.67 & 2.00 & 0.00 & 3.33 & 6.00 & $2.80 \mathrm{~h}$ \\
$26 \% / 72$ jam & 2.67 & 4.00 & 16.67 & 20.00 & 14.67 & $11.60 \mathrm{~g}$ \\
\hline Rataan & $48.54 \mathrm{a}$ & $55.58 \mathrm{a}$ & $58.73 \mathrm{a}$ & $54.9 \mathrm{a}$ & $37.67 \mathrm{~b}$ &
\end{tabular}

Ket.: Nilai yang diikuti huruf yang sama tidak berbeda berbeda nyata pada uji DMRT 5\%; data sebelum diolah dengan uji F ditransformasi $(\mathrm{x}+0.5)^{1 / 2}$

Pengaruh faktor tunggal varietas dan faktor kondisi $C D T$ pada variabel $\mathrm{K}_{\mathrm{CT}}$ ditunjukkan pada Tabel 3.Pengaruh faktor varietas terhadap $\mathrm{K}_{\mathrm{CT}}$ tidak berbeda nyata pada kelima kecuali pada Vima-1.
Pada faktor tunggal kondisi $C D T$ semakin ditingkatkan kadar air dan lama penderaan menyebabkan nilai $\mathrm{K}_{\mathrm{CT}}$ menurun dan berbeda nyata dengan 0 jam.

Tabel 3. Pengaruh faktor tunggal varietas dan kondisi $C D T$ terhadap $\mathrm{K}_{\mathrm{CT}}$ (\%/etmal)

\begin{tabular}{|c|c|c|c|c|c|c|}
\hline \multirow{2}{*}{$\begin{array}{c}\text { Kondisi } C D T \text { (KA/Lama } \\
\text { penderaan) }\end{array}$} & \multicolumn{5}{|c|}{ Varietas } & \multirow{2}{*}{ Rataan } \\
\hline & Walet & Sriti & Murai & Kutilang & Vima-1 & \\
\hline $20 \% / 0$ jam & 28.37 & 30.68 & 31.44 & 29.68 & 28.23 & $29.68 \mathrm{a}$ \\
\hline $20 \% / 24$ jam & 22.10 & 21.58 & 26.33 & 23.13 & 16.33 & $21.89 \mathrm{~b}$ \\
\hline $20 \% / 48$ jam & 14.86 & 19.98 & 15.07 & 19.68 & 8.32 & $15.58 \mathrm{~cd}$ \\
\hline $20 \% / 72$ jam & 14.50 & 15.24 & 19.61 & 20.60 & 8.64 & $15.70 \mathrm{~cd}$ \\
\hline $22 \% / 0$ jam & 28.50 & 30.80 & 30.80 & 28.94 & 26.11 & $29.03 \mathrm{a}$ \\
\hline $22 \% / 24 \mathrm{jam}$ & 15.85 & 24.78 & 25.83 & 18.61 & 10.22 & $19.06 b c$ \\
\hline $22 \% / 48$ jam & 14.89 & 18.20 & 9.67 & 7.52 & 3.83 & $10.82 \mathrm{ef}$ \\
\hline $22 \% / 72$ jam & 7.76 & 4.27 & 10.01 & 9.12 & 7.24 & $7.68 \mathrm{f}$ \\
\hline $24 \% / 0$ jam & 28.36 & 30.49 & 30.38 & 28.10 & 26.44 & $28.75 \mathrm{a}$ \\
\hline $24 \% / 24$ jam & 13.27 & 17.39 & 18.3 & 11.42 & 5.51 & $13.18 \mathrm{de}$ \\
\hline $24 \% / 48$ jam & 2.79 & 6.82 & 4.38 & 3.76 & 1.83 & $3.92 \mathrm{~g}$ \\
\hline $24 \% / 72$ jam & 4.23 & 1.32 & 3.62 & 7.94 & 5.28 & $4.48 \mathrm{~g}$ \\
\hline $26 \% / 0$ jam & 26.62 & 26.10 & 30.10 & 29.36 & 24.5 & $27.37 \mathrm{a}$ \\
\hline $26 \% / 24$ jam & 8.94 & 10.69 & 11.84 & 9.23 & 2.56 & $8.65 \mathrm{f}$ \\
\hline $26 \% / 48$ jam & 0.78 & 0.49 & 0.00 & 1.00 & 1.78 & $0.81 \mathrm{~h}$ \\
\hline $26 \% / 72$ jam & 0.89 & 1.22 & 4.46 & 5.47 & 4.50 & $3.31 \mathrm{~g}$ \\
\hline Rataan & $14.54 \mathrm{a}$ & $16.25 \mathrm{a}$ & $16.99 a$ & $15.84 \mathrm{a}$ & $11.33 b$ & \\
\hline
\end{tabular}

Ket.: Nilai yang diikuti huruf yang sama tidak berbeda berbeda nyata pada uji DMRT 5\%; data sebelum diolah dengan uji F ditransformasi (x+0.5) ${ }^{1 / 2}$

Pengaruh faktor tunggal varietas dan kondisi CDT pada variabel IV ditunjukkan pada Tabel 4. Pengaruh kondisi $C D T$ terhadap IV mulai terlihat pada kondisi $20 \% / 48$ jam yang berbeda dengan
0 jam. Semakin ditingkatkan lama penderaan menjadi 72 jam dan KA menjadi $24 \%$ dan $26 \%$ menyebabkan nilai IV menurun. 
Tabel 4. Pengaruh faktor tunggal varietas dan kondisi $C D T$ terhadap IV (\%)

\begin{tabular}{|c|c|c|c|c|c|c|}
\hline \multirow{2}{*}{$\begin{array}{c}\text { Kondisi } C D T(\mathrm{KA} / \mathrm{Lama} \\
\text { penderaan })\end{array}$} & \multicolumn{5}{|c|}{ Varietas } & \multirow{2}{*}{ Rataan } \\
\hline & Walet & Sriti & Murai & Kutilang & Vima-1 & \\
\hline $20 \% / 0$ jam & 92.00 & 98.67 & 99.33 & 98.67 & 92.67 & $96.27 \mathrm{a}$ \\
\hline $20 \% / 24$ jam & 74.67 & 72.67 & 89.33 & 82.67 & 56.00 & $75.07 \mathrm{ab}$ \\
\hline $20 \% / 48$ jam & 51.33 & 70.67 & 69.00 & 69.33 & 28.67 & $57.00 \mathrm{bcd}$ \\
\hline $20 \% / 72$ jam & 48.00 & 52.00 & 68.67 & 71.33 & 30.00 & $54.00 \mathrm{~cd}$ \\
\hline $22 \% / 0$ jam & 92.67 & 98.67 & 98.00 & 98.00 & 84.67 & $94.40 \mathrm{a}$ \\
\hline $22 \% / 24$ jam & 52.00 & 85.33 & 88.67 & 66.00 & 35.33 & $65.47 b c$ \\
\hline $22 \% / 48$ jam & 54.00 & 66.00 & 34.67 & 24.00 & 12.67 & $38.27 \mathrm{ef}$ \\
\hline $22 \% / 72$ jam & 26.67 & 14.67 & 34.67 & 32.00 & 24.00 & $26.40 \mathrm{f}$ \\
\hline $24 \% / 0$ jam & 92.00 & 98.00 & 97.33 & 95.33 & 84.67 & $93.47 \mathrm{a}$ \\
\hline $24 \% / 24$ jam & 45.33 & 58.67 & 64.00 & 42.00 & 18.67 & $45.73 \mathrm{de}$ \\
\hline $24 \% / 48$ jam & 10.67 & 24.67 & 16.67 & 12.67 & 6.00 & $14.13 \mathrm{~g}$ \\
\hline $24 \% / 72$ jam & 14.67 & 5.33 & 10.67 & 28.67 & 16.67 & $15.20 \mathrm{~g}$ \\
\hline $26 \% / 0$ jam & 87.33 & 95.33 & 97.33 & 98.67 & 78.67 & $91.47 \mathrm{a}$ \\
\hline $26 \% / 24$ jam & 28.00 & 38.00 & 40.00 & 30.67 & 8.67 & $29.07 \mathrm{f}$ \\
\hline $26 \% / 48$ jam & 2.67 & 2.00 & 0.00 & 3.33 & 6.00 & $2.80 \mathrm{i}$ \\
\hline $26 \% / 72$ jam & 2.67 & 4.00 & 14.67 & 20.00 & 14.67 & $11.20 \mathrm{~h}$ \\
\hline Rataan & $48.41 \mathrm{a}$ & $55.23 a$ & $57.44 a$ & $54.58 \mathrm{a}$ & $37.37 \mathrm{~b}$ & \\
\hline
\end{tabular}

Ket.: Nilai yang diikuti huruf yang sama tidak berbeda berbeda nyata pada uji DMRT 5\%; data sebelum diolah dengan uji F ditransformasi $(x+0.5)^{1 / 2}$

Penurunan vigor benih pada kondisi $C D T$ ketika dilakukan penderaan khususnya pada penderaan 48 jam dan 72 jam yang terlihat pada variabel $\% \mathrm{KN}, \mathrm{K}_{\mathrm{CT}}$ dan IV diduga disebabkan karena proses metabolisme yang terus menerus dan cepat pada water bath bersuhu $45^{\circ} \mathrm{C}$. Secara umum, viabilitas dan vigor benih menurun sejalan dengan meningkatnya suhu, dan semakin lamanya benih terkena suhu tinggi, serta dengan meningkatnya kandungan air benih (Justice dan Bass, 2002). Metode CDT digunakan untuk menyeleksi vigor beberapa varietas. Pada faktor tunggal varietas (variabel $\% \mathrm{KN}, \mathrm{K}_{\mathrm{CT}}$ dan IV) varietas Vima-1 merupakan varietas yang memiliki vigor berbeda dengan varietas lainnya. Pada faktor tunggal kondisi $C D T$ (variabel $\% \mathrm{KN}, \mathrm{K}_{\mathrm{CT}}$ danIV) semua varietas menunjukkan respon yang sama. Dasar pemilihan kondisi $C D T$ yang digunakan adalah yang hasil statistiknya berbeda dengan 0 jam dan tidak ada nilai 0. Dasar lain yaitu pada efektifitas dan efisiensi waktu dalam pelaksanaan.

Hasil analisis statistik pada variabel pengamatan $\% \mathrm{KN}$ dengan kondisi CDT 20\%/48 jam menunjukkan nilai yang berbeda dengan kontrol, sedangkan pada lama penderaan 72 jam nilai sudah rendah. Kondisi $C D T 22 \% / 24$ jam tidak berbeda dengan 20\%/48 jam sedangkan kondisi KA 22\% dengan lama penderaan 48 dan 72 nilai $\% \mathrm{KN}$ sudah rendah. Kondisi KA $24 \%$ dan $26 \%$ juga menunjukkan nilai yang sudah sangat rendah. Hal yang sama terjadi pada variabel $\mathrm{K}_{\mathrm{CT}}$ dan IV. Maka, kondisi $C D T$ yang akan diuji korelasi dengan percobaan PEG terpilih (tekanan osmotik -1 bar) adalah kondisi CDT (kadar air/lama penderaan) $20 \% / 48$ jam dan 22\%/24 jam.

Korelasi antara Berbagai Variabel Percobaan Tekanan Osmotik PEG $6000-1$ bar $\left(V_{K T}^{\text {kekeringan }}\right)$ dengan $C D T\left(V_{C D T}\right)$

Metode $C D T$ dikembangkan untuk menguji vigor berbagai jenis benih yang dapat menggambarkan keadaan benih di lapang. Kondisi CDT yang digunakan pada penelitian ini digunakan untuk menggambarkan potensi vigor kekuatan tumbuh lima varietas benih kacang hijau pada cekaman kekeringan. Hasil penelitian pada benih kedelai menunjukkan bahwa $C D T$ berkorelasi nyata dengan kondisi deraan cuaca di lapang $\left(\mathrm{V}_{\mathrm{KT}}\right.$ field waeathering) (Changrong et al., 2007). Hasil penelitian Aryati (2011), CDT kondisi kadar air 20\% dan lama penderaan 48 jam pada benih padi berkorelasi nyata dengan cekaman kekeringan $\left(\mathrm{V}_{\mathrm{KT}^{\mathrm{k}}}{ }^{\text {keringan }}\right)$.

Hasil penelitian ini menunjukkan korelasi positif nyata pada variabel $\% \mathrm{KN}$ kondisi $20 \% / 48$ jam dan 22\%/24 jam dengan nilai $r$ yaitu 0.61 dan 0.62 yang merupakan nilai yang hampir sama cukup tinggi. Hal ini menunjukkan keeratan hubungan antara $\mathrm{V}_{\mathrm{KT}}{ }^{\text {kekeringan }}$ dengan $\mathrm{V}_{C D T}$ yang positif pada variabel $\% \mathrm{KN}$. Korelasi positif nyata juga ditunjukkan pada variabel $\mathrm{K}_{\mathrm{CT}}$ kondisi 20\%/48jam dan 22\%/24 jam dengan nilai koefisien korelasi sebesar 0.58 dan 0.59 . Nilai tersebut cukup erat untuk menggambarkan hubungan antara $\mathrm{V}_{\mathrm{KT}}{ }^{\text {kekeringan }}$ dengan $\mathrm{V}_{C D T}$ pada variabel $\mathrm{K}_{\mathrm{CT}}$.

Korelasi yang cukup erat pada variabel $\% \mathrm{KN}$ dan $\mathrm{K}_{\mathrm{CT}}$ pada tekanan osmotik PEG 6000 -1 bar 
dengan $\mathrm{V}_{C D T}$ berdasarkan nilai $\mathrm{r}$ dan $\mathrm{R}^{2}$ dapat menjadi indikator bahwa perlakuan CDT (20\%/48 jam dan 22\%/24 jam) dapat digunakan untuk menguji ketahanan benih kacang hijau terhadap cekaman kekeringan setara dengan tekanan osmotik -1 bar.

\section{KESIMPULAN}

Tingkat tekanan osmotik PEG 6000 -1 bar merupakan tingkat yang tepat untuk membedakan ketahanan benih terhadap cekaman kekeringan lima lot benih kacang hijau. Berdasarkan hasil uji cekaman kekeringan dengan PEG, dapat dikelompokkan varietas yang tahan kekeringan yaitu varietas Sriti dan Walet, dan yang tidak tahan kekeringan yaitu varietas Murai, Kutilang dan Vima-1.

Metode $C D T$ kondisi 20\%/48 jam dan 22\%/24 jam dengan suhu water bath $45^{\circ} \mathrm{C}$ merupakan kondisi yang tepat untuk menguji vigor benih kacang hijau.

Hasil analisis korelasi dan regresi membuktikan bahwa metode CDT kondisi 20\%/48 jam dan 22\%/24 jam memiliki korelasi yang nyata dengan PEG 6000 -1 bar pada variabel \% KN dengan nilai $r$ masing-masing sebesar 0.61 dan 0.62 serta pada variabel $\mathrm{K}_{\mathrm{CT}}$ dengan $\mathrm{r}$ masing-masing sebesar 0.58 dan 0.59. Perlakuan CDT kadar air $20 \%$ dengan lama penderaan 48 jam dan kadar air $22 \%$, lama penderaan 24 dengan suhu water bath $45^{\circ} \mathrm{C}$ jam dapat digunakan untuk menguji ketahanan benih kacang hijau terhadap cekaman kekeringan setara dengan tekanan osmotik -1 bar.

\section{DAFTAR PUSTAKA}

Abdurrachman, A., A. Dariah, A. Mulyani. 2008. Strategi dan teknologi pengelolaan lahan kering mendukung pengadaan pangan nasional. J. Litbang Pert. 27(2):43-49.

Aryati, V. 2011. Metode Pengusangan Cepat Terkontrol untuk Mengidentifikasi Secara Dini Genotipe Padi Gogo (Oryza sativa L.) Toleran Kekeringan. Tesis. Program Pascasarjana, Institut Pertanian Bogor. Bogor. 47 hal.

Balitkabi. 2005. Deskripsi Varietas Unggul Kacang-kacangan dan Umbi-umbian. Balai Penelitian Tanaman Kacang-kacangan dan Umbi-umbian. Malang. 154 hal.

Changrong, Y., P. Sripichitt, S. Juntakool, V. Hongtrakul, A. Sripichitt. 2007. Modifying controlled deterioration for evaluating field weathering resistance of soybean. Kasetsart J. (Nat. Sci.) $41: 232-241$.

Dutta, P., A.K. Bera. 2008. Screening of mungbean genotipes for drought tolerance. Legume Res 31(2): $145-148$.

Justice, O.L., L.N. Bass. 1994. Prinsip dan Praktek Penyimpanan Benih (diterjemahkan dari : Principles and Practices of Seed Storage, penerjemah R. Roesli). Cetakan kedua. PT Raja Grafindo Persada. Jakarta. 446 hal.

Lestari, E.G., I. Mariska. 2006. Identifikasi somaklon padi Gajahmungkur, Towuti dan IR 64 tahan kekeringan menggunakan Polyethylene Glycol. Bul. Agron. 34(2):7178.

Michel, B.E., M.R. Kaufman. 1973. The osmotic potential of polyethylene glycol 6000. Plant Pysiol. 57.57:914-916.

Sadjad, S., E, Murniati, dan S. Ilyas. 1999. Parameter Pengujian Vigor Benih dari Komparatif ke Simulatif. Grasindo. Jakarta. 185 hal.

Wafiroh, S. 2010. Pengujian Vigor Benih Menggunakan Metode Controlled Deterioration Test dan Korelasinya terhadap Daya Tumbuh dan Vigor Bibit Wijen (Sesamum indicum L.). Skripsi. Program Sarjana, Institut Pertanian Bogor. Bogor. 49 hal.

Widoretno, W., E. Guhardja, S. Ilyas, Sudarsono. 2002. Efektivitas polietilena glikol untuk mengevaluasi tanggapan genotipe kedelai terhadap cekaman kekeringan pada fase perkecambahan. Hayati. 9 (2):33-36.

Zayed, M.A., I.M. Zeid. 1997. Effect of water and salt stresses on growth, clorophyll, mineral ions and organic solutes contents, and enzymes activity in mungbean seedlings. Biologia Plantarium 40(3):351-356. 